\title{
НЕКОТОРЫЕ РЕЗУЛЬТАТЫ ПРИМЕНЕНИЯ ТЕРМОЛЮМИНЕСЦЕНТНОГО МЕТОДА ДЛЯ ДАТИРОВАНИЯ ПЛЕЙСТОЦЕНОВЫХ ОТЛОЖЕНИЙ ЮГО-ВОСТОЧНОЙ ЛАТВИИ
}

Как известно, расчленение и корреляция четвертичных образований нередко вызывают значительные трудности, обусловленные наблюдаемой неполнотой геологических разрезов, отсутствием ряда слоев, даже свит и горизонтов в них, а также наличием в толще четвертичных отложений отторженцев подстилающих пород, малой эффективностью отдельных методов исследований и т. д. Поэтому не удивительно, что по расчленению некоторых разрезов споры не прекращаются до сих пор и существует несколько точек зрения, которые зачастую невозможно ни доказать, ни опровергнуть с помощью одних только стратиграфических методов.

Для преодоления этих трудностей новые возможности открывают геохронологические исследования четвертичных отложений. В связи с этим интерес могут представлять определения абсолютного возраста отложений некоторых разрезов юго-востока Латвии, проведенные нами термолюминесцентным (ТЛ) методом.

Одним из основных опорных разрезов плейстоценовых отложений Латвии является разрез Жидини, представления о стратиграфии которого основываются главным образом на палинологическом изучении межледниковых озерных отложений, залегающих в нижней части разреза под тремя моренами, разделенными толщами водноледниковых осадков (рисунок). В настоящее время наиболее общепринятой является точка зрения о раннечетвертичном возрасте межледниковых образований (Даниланс и др., 1964; Даниланс, 1973; Вознячук, 1966; Вознячук, Пузанов, 1967; Салов, 1970; Горецкий, 1972; Гуделис, 1973 и др.), хотя имеются и иные взгляды (Москвитин, 1976). В соответствии с этим наиболее вероятным было признано отнесение перекрывающей межледниковые отложения зеленовато-серой морены к летижскому (миндельскому, дайнавскому) оледенению, а залегающей выше серовато-бурой морены - ко времени курземского (рисского, среднерусского) оледенения, самой верхней моренной толщи бурого и красноватобурого цвета - к балтийскому (вюрмскому, валдайскому) оледенению. С помощью ТЛ-метода была сделана попытка определить возраст межморенных алевритовых отложений, залегающих между красно-бурой и серовато-бурой моренами, серовато-бурой морены и подстилающих ее межморенных глинистых осадков.

Возраст межморенных алевритовых отложений 79150 лет (TlnTL-45) скорее всего свидетельствует об их накоплении во время начала вюрма (валдая). В таком случае возраст залегающей ниже сероватобурой морены, датирование которой не дало конечного результата, - 


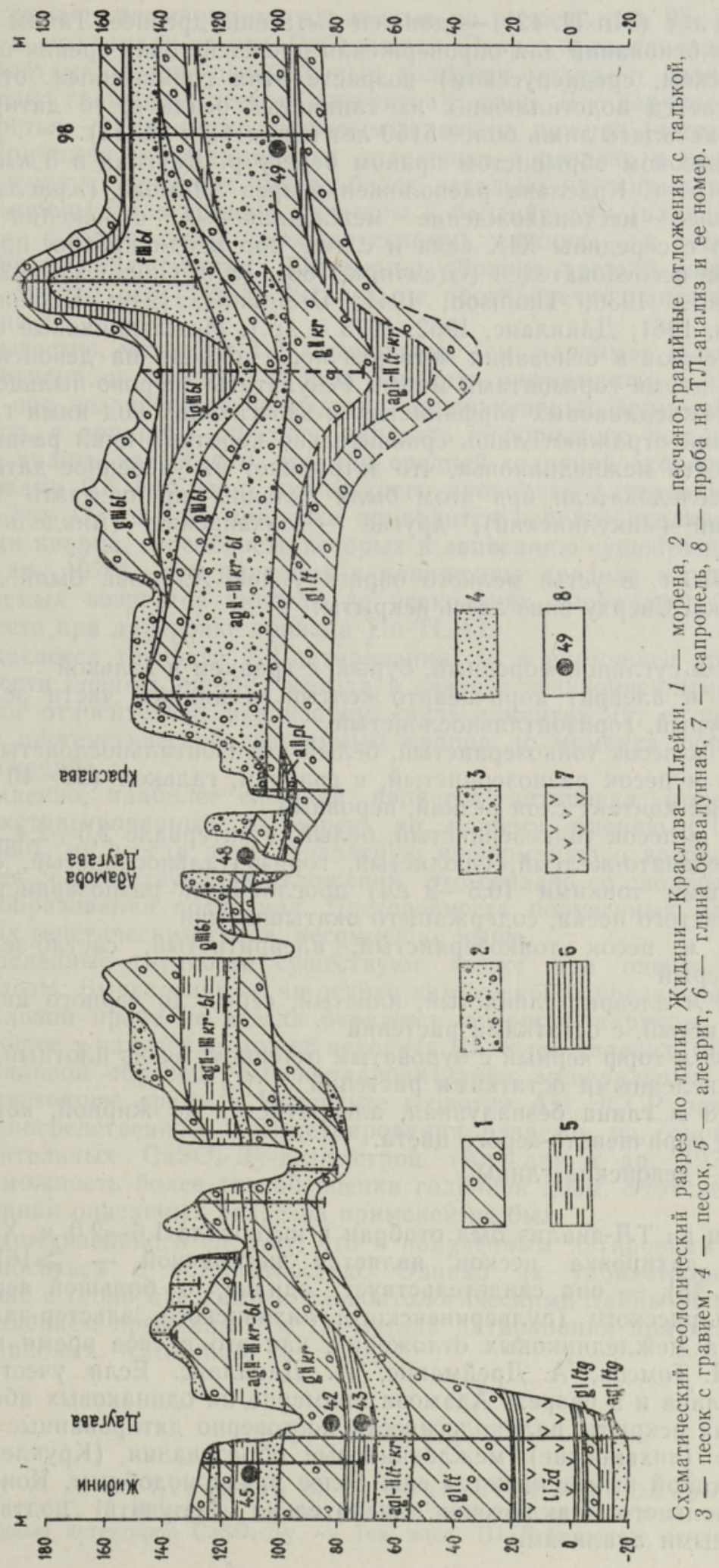

3 ENS̀V TA Toimetised. G 11981 
$>68800$ лет (Tln-TL-42) - должен быть еще древнее. Таким образом, пока нет оснований для опровержения прежней точки зрения о рисском (курземском, среднерусском) возрасте этих гляцигенных отложений. Что касается подстилающих их глинистых осадков, то датировка их по ТЛ оказалась лишь более 5150 лет назад (Tln-TL-43).

На высоком обрывистом правом берегу р. Даугава в $3 \kappa м$ вниз по течению от г. Краслава расположен разрез Адамова (Краслава). Это древнейшее местонахождение межледниковых отложений Латвии известно с середины XIX века и с тех пор неоднократно привлекало внимание исследователей (Grewingk, 1861, 1879; Galenieks, 1926; Kraus, 1928; Zāns, 1936; Thomson, 1941; Dreimanis, 1949; Перконс, 1957; Sprinğis, 1961; Даниланс, 1962, 1973 и др.). Межледниковые образования залегают в основании четвертичного покрова на девонских породах под двумя горизонтами морен. Результаты спорово-пыльцевых анализов межледниковых торфянистых и залегающих под ними глинистых отложений отражают лишь сравнительно короткий цикл развития растительности межледниковья, что затрудняет их уверенное датирование. Одни исследователи при этом были склонны приписывать им риссвюрмский (микулинский), другие - лихвинский (миндель-рисский) возраст.

В 1976 г. в устье мелкого́ оврага у пос. Адамова была заложена расчистка. Сверху вниз здесь вскрыты:

$0,0-0,5$ м суглинок моренный, бурый, с гравием и галькой

0,5-1,0 $\mu$ алеврит коричневато-желтый, в нижней части зеленоватобурый, горизонтальнослоистый

$1,0-1,3 м$ песок тонкозернистый, белый, горизонтальнослоистый

1,3-1,6 м песок разнозернистый, с гравием, галькой $(30-40 \%)$; нижний контакт слоя резкий, неровный

1,6-2,9 м песок тонкозернистый, белый, в интервале 2,0-2,4 $\mu$ светлосеровато-желтый, слюдистый, горизонтальнослоистый, с отдельными тонкими $(0,5-2$ см) прослойками разнозернистого гравистого песка, содержащего окатыши глин

2,9-3,3 м песок .тонкозернистый, алевритистый, светло-зеленоватосерый

3,3-4,2 $м$ алеврит глинистый, илистый, серый до черного цвета, слюдистый, с остатками растений

4,2-4,55 м торф черный с буроватым оттенком, очень плотный, с многочисленными остатками растений

4,55-5,8 м глина безвалунная, алевритистая до жирной, коричневого и коричневато-серого цвета.

Ниже - девонские глины.

Образец на ТЛ-анализ был отобран в интервале $1,6-2,0$ м. Хотя полученная датировка песков является неконечной - $\geqslant 161550$ лет (Tln-TL-48) - она свидетельствует, однако, о большой вероятности миндель-рисского (пулверниекского, лихвинского, эльстер-заальского) возраста межледниковых отложений, как это в свое время предполагали П. Томсон, А. Дрейманис, И. Даниланс. Если учесть, что в г. Краслава и в разрезе Адамова примерно на одинаковых абсолютных отметках вскрыты палинологически достоверно датированные миндельрисские (лихвинские) межледниковые образования (Крукле, Стелле, 1964), такой вывод кажется еще более правдоподобным. Конечно, для окончательного заключения желательно получить подтверждение повторными анализами. 
Заслуживают внимания также данные по разрезу скв. 98, расположенному к юго-западу от пос. Робежниеки. Разрез представлен четырьмя горизонтами морен, разобщенных толщами мелко- и разнозернистых, нередко гравистых песков, алевритов и глин. Две верхние морены бурые, третья - бурая с красноватым оттенком, нижняя (четвертая) бурая. Принимая во внимание их положение в разрезе и результаты сопоставления с моренами других более детально изученных разрезов, верхние морены были условно отнесены к балтийскому (валдайскому), средняя - к курземскому (среднерусскому), нижняя - к летижскому (дайнавскому) оледенениям. ТЛ-возраст образца третьей морены составляет 106250 лет (Tln-TL-49), что не противоречит ранее полученным данным.

Как известно, методика ТЛ-датирования (см. например, Хютт и др., 1977) основана на свойстве кварца запасать информацию в виде светосуммы под воздействием природных радиоактивных примесей $\mathrm{U}$, Th, ${ }^{40} \mathrm{~K}$. Кварц, в принципе, способен запасать информацию под воздействием доз вплоть до $10^{6}$ рад, что при средней годичной скорости облучения дозами 0,5 рад дает возможность проводить датировки вплоть до $5 \cdot 10^{6}$ лет. Однако на практике приходится нередко сталкиваться с образцами кварца, способность которых к запасанию существенно ниже (Hütt и др., 1979). Это приводит к понижению предела максимально определяемых возрастов (иногда до нескольких тысяч лет), как это имело место при датировке образца Tln-TL-43.

Что касается точности ТЛ-датирования, то в настоящее время нет возможности оценить ошибку метода в связи с незаконченными исследованиями относительно реализации «нуль-момента» (т. е. проблемы стирания прогенетической светосуммы кварца до момента формирования отложений).

Несомненно, наиболее сложной является датировка морен. Так, кварц, экстрагированный из морен, по нашему мнению (Лийвранд и др., 1980), не всегда дает адекватную информацию о возрасте формирования соответствующих отложений. Это связано со сложным механизмом образования последних. Достоверность полученных датировок остальных генетических типов, несомненно, выше.

Определенные трудности существуют также при оценке среднегодовой дозы. Вычисление ее на основе химического определения $\mathrm{U}, \mathrm{Th}$, ${ }^{40} \mathrm{~K}$ в валовой пробе не всегда отражает истинную картину, так как проникающее $\gamma$-излучение может исходить из более далеких (не попавших в валовой образец) высокорадиоактивных минеральных включений. В настоящее время в Институте геологии АН ЭССР разработан метод непосредственного дозиметрирования разрезов на основе высокочувствительных $\mathrm{CaSO}_{4}$-Ду-дозиметров (Аллсалу и др., 1979), что дает возможность более точной оценки годичной дозы. Этот метод при исследовании описанных разрезов применен не был.

Из вышеуказанного следует, что к полученным датировкам необходимо относиться с осторожностью. Однако их удовлетворительное совпадение с геологическими и палеонтологическими данными является подтверждением применимости ТЛ-метода датирования при исследовании ледниковых отложений.

\section{ЛИТЕРАТУРА}

Аллсалу М. Л. Ю., Керикмяэ М. П., Пуннинг Я.-М. К., Смирнов А. А., $\mathrm{X}$ ю т т Г. И. Измерение уровня фоновой радиации окружающей среды с помощью детекторов $\mathrm{CaSO}_{4}$-Ду. - Тез. докл. III Всесоюзного симпознума по 
люминесцентным приемникам и преобразователям рентгеновского излучения, $11-13$ апреля 1979 г. Ставрополь, 1979.

В озн я у к Л. Н. О стратиграфическом подразделении среднечетвертичных отложений в древнеледниковой области Русской равнины. - Мат. четвертой конференции геологов Белоруссии и Прибалтики. Минск, 1966, 181-189.

Возня чук Л. Н, Пузанов Л. Т. К вопросу о геологическом возрасте отложений беловежского межледниковья. - Док. АН БССР, 1967, 11, 713-716.

Г орецкий Г. И. Ложбины ледникового выпахивания и размыва в их связи с краевыми ледниковыми образованиями. - В кн.: Ледниковый морфогенез. Рига, $1972,19-39$.

Гудели с В. К. Рельеф и четвертичные отложения Прибалтики. Вильнюс, 1973.

Даниланс И. Я. Вопросы стратиграфии плейстоценовых отложений Латвии. Вопросы четвертичной геологии. І. Рига, 1962, 7-45.

Л ани л ан с И. Я. Четвертичные отложения Латвии. Рига, 1973.

Данилан С И. Я., Дзилна В. Я., Стелле В. Я. Разрез Жидини. - Вопросы четвертичной геологии. ІІІ. Рига, 1964, 63-140.

Крукле М.Я., Стелле В. Я. Миндель-рисские отложения в городе Краслава. Вопросы четвертичной геологии. III. Рига, 1964, 165-182.

Лйй ранд Э. Д., Пуннинг Я.-М. К., Р аукас А. В., Хютт Г. И. Об эффективности разных методов исследования в выяснении возраста отложений в верхнеплейстоценовом стратотипическом разрезе Пээду (Юго-Восточная Эстония). - В кн.: Геохронология четвертичного периода. М., 1980, 54-62.

Москвитин А. И. Опорные разрезы плейстоцена Русской равнины. М., 1976 , $123-128$.

Перконс В. А. К вопросу стратиграфии плейстоценовых отложений Латвийской ССР. - Тр. регионального совещания по изучению четвертичных отложений Прибалтики и Белоруссии. Науч. сооб. Ин-та геологии и географии АН Лит, ССР. Вильнюс, 1957, вып. 4, 175-187.

С алов И. Н. О древнейших межледниковых отложениях северо-запада Русской равнины. - Мат. по геологии и полезным ископаемым центральных районов Европейской части СССР. М.. 1970, вып. 6, 258-265.

Х ют т Г., Пуннинг Я.-М., С ми рнов А. Методика термолюминесцентного датирования в геологии. - Изв. АН ЭССР. Хим. Геол., 1977, 26, $284-288$.

D reima n is, A. Interglacial deposits of Latvia. - Geol. 'fören. Stockholm förhandl., $1949,71,525-536$.

Ga lenieks, P. The interglacial flora of Kräslava. - Acta horti bot. Univ. Latv., 1926, I, $179-194$.

Grewingk, C. Geologie von Liv- und Kurland mit Inbegrifi einiger angrenzenden Gebiete. - Arch. Naturk. Liv-, Est- und Kurlands, Ser. 1, 1861, 2, 479-776.

Grewingk, C. Erläuterungen zur zweiten Ausgabe der geognostischen Karte Liv-, Est- und Kurlands. -. Arch. Naturk. Liv-, Est- und Kurlands, Ser. 1, 1879, 8. $343-465$.

$\mathrm{Hüt}$, G., S mirnov, A., T a le, I. On the application of thermoluminescence of natural quartz to the study of geochronology of sedimentary deposits. I. Pact 3, 1979, 362-373.

Kraus, E. Tertiär und Quartär des Ostbaltikums. - Die Kriegsschauplätze 1914-1918 geologisch dargestellt. I Teil, Berlin, 1928, 10, 142.

S p r i ṇ g is, K. Pleistocēna nogulumi. - Latvijas PSR g̉eolog̉ija. Rìga, 1961, 114-175.

Thomson, P. W. Die Klima- und Waldentwicklung des von K. Orviku entdeckten Interglazials von Ringer bei Dorpat (Estland). — Z. Dtsch. Geol. Ges., 1941, 93, $275-282$.

Zã ns, V. Leduslaikmets un pēcleduslaikmets Latvijā. - Latvijas zeme, daba un tauta. 1. sēj. Rìga, 1936, 49-124.

Управление геологии Латвийской ССР

Поступила в редакцию Институт геологии 26/V 1980

\section{Академии наук Эстонской ССР}


Z. MEIRONS, J.-M. PUNNING, Galina HUTT

\section{KAGU-LÄTI PLEISTOTSEENI SETETE TERMOLUMINESTSENTSDATEERIMISE TULEMUSTEST}

Termoluminestsentsimeetodil on määratud setete moodustumise aeg mõningates Kag!iLäti pleistotseeni läbilōigetes. Zidini läbilōikes on punakaspruuni (würm, balti) ja hallikaspruuni (riss, kurzeme) moreeni vahel lasuvate aleuriitide vanus 79150 aastat (Tln-TL-45). Rissi moreeni vanuseks Zidini läbilöikes saadi $>68800$ (Tln-TL-42) ja Robesnieki läbilõikes 106250 aastat (Tln-TL-49). Adamova (Kraslava) läbilõikes saadi moreenidevaheliste liivade vanuseks $>161550$ aastat (Tln-TL-48), mis kinnitab palünoloogilist dateeringut (mindel-riss).

\section{Z. MEIRONS, J.-M. PUNNING, Galina HOTT}

\section{RESULTS OBTAINED THROUGH THE TL DATING OF SOUTH-EAST LATVIAN PLEISTOCENE DEPOSITS}

The age of the formation of deposits was determined using the TL method in several Pleistocene profiles in SE Latvia. Silts between the reddish-brown (Würm, Baltic) and greyish-brown (Riss, Kurzeme) tills in the Zidini section yielded the age of 79150 years (Tln-TL-45). The riss till is $>68800$ (Tln-TL-42) years of age in the Zidini section and 106250 (Tln-TL-49) in the Robesnieki section. In the Adamova (Kraslava) section the sands embedded in the till yielded the age of $>161550$ years (Tln-TL-48), whịch agrees with palynologic data (Mindel-Riss). 